\title{
Preparedness and guidelines for neurosurgery in the COVID-19 era: Indian perspective from a tertiary care referral hospital
}

\author{
*Amol Raheja, MCh, ${ }^{1}$ Nitish Agarwal, MCh, ${ }^{1}$ Sarita Mohapatra, MD, ${ }^{2}$ Vivek Tandon, MCh, \\ Sachin Anil Borkar, MCh, ${ }^{1}$ P. Sarat Chandra, MCh, ${ }^{1}$ Shashank S. Kale, MCh, ${ }^{1}$ and Ashish Suri, MCh${ }^{1}$ \\ Departments of ${ }^{1}$ Neurosurgery and ${ }^{2}$ Microbiology, All India Institute of Medical Sciences, New Delhi, India
}

The COVID-19 pandemic has severely impacted healthcare systems globally. The need of the hour is the development of effective strategies for protecting the lives of healthcare providers (HCPs) and judicious triage for optimal utilization of human and hospital resources. During this pandemic, neurosurgery, like other specialties, must transform, innovate, and adopt new guidelines and safety protocols for reducing the risk of cross-infection of HCPs without compromising patient care. In this article, the authors discuss the current neurosurgical practice guidelines at a high-volume tertiary care referral hospital in India and compare them with international guidelines and global consensus for neurosurgery practice in the COVID-19 era. Additionally, the authors highlight some of the modifications incorporated into their clinical practice, including those for stratification of neurosurgical cases, patient triaging based on COVID-19 testing, optimal manpower management, infrastructure reorganization, evolving modules for resident training, and innovations in operating guidelines. The authors recommend the use of their blueprint for stratification of neurosurgical cases, including their protocol for algorithmic patient triage and management and their template for manpower allocation to COVID-19 duty, as a replicable model for efficient healthcare delivery.

https://thejns.org/doi/abs/10.3171/2020.9.FOCUS20564

KEYWORDS COVID-19; neurosurgery guidelines; Indian scenario; triage; diagnostic testing; manpower allocation

$\mathrm{N}$ OVEL coronavirus disease 2019 (COVID-19) was first reported in the city of Wuhan, China, in December 2019. Since that time, there has been an exponential increase in the number of cases, from a few hundred to 8.3 million at the time of this writing. This increase has been accompanied by a meteoric rise in the literature on COVID-19, with more than 18,000 publications reported to date. As the number of scientific reports increases daily, it becomes imperative to filter the grain from the chaff and provide updates and recommendations for the neurosurgical discipline, where practice patterns have seen a sea change. The already-overburdened healthcare delivery systems of developing countries like India have come under severe stress due to the rapid increase of cases. At the time of the submission of this paper for publication, more than 367,000 positive cases with more than 12,000 deaths have been attributed to COVID-19 in India. We have adapted and restructured our treatment and resource allocation to improve healthcare delivery. In this article, we share our experience and present a comprehensive review of guidelines, suggestions, and recommendations pertaining to neurosurgical practice in a developing country amid the COVID-19 pandemic. Our replicable patient triage algorithm, management protocols, and template for judicious manpower reallocation can be useful for many centers dealing with the pandemic. To prepare this article, we carried out a review of articles on PubMed on June 4, 2020, by using the keywords "COVID-19" and "neurosurgery." The search yielded 295 articles, which we reviewed for relevance. References from relevant articles were reviewed to locate other articles of interest. Additionally, documents published on websites of various international and national neurosurgical and relevant medical societies were also included. ${ }^{1-7}$ We have divided the article into the following five sections: 1) reorganization of infrastructure and manpower, 2) clinic scheduling and telemedicine, 3) surgical scheduling, 4) neurosurgical training and education, and 5) structural allocation of multidepartment

ABBREVIATIONS CB-NAAT = cartridge-based nucleic acid amplification test; $\mathrm{HCP}=$ healthcare provider; $\mathrm{HICC}=$ hospital infection control committee; LLI = influenza-like illness; $\mathrm{OR}=$ operating room; $\mathrm{PCR}$ = polymerase chain reaction; $\mathrm{PPE}=$ personal protective equipment; $\mathrm{RT}-\mathrm{PCR}$ = reverse transcription-PCR; $\mathrm{SARI}=$ severe acute respiratory infection; TrueNAT = chip-based PCR assay.

SUBMITTED June 18, 2020. ACCEPTED September 24, 2020.

INCLUDE WHEN CITING DOI: 10.3171/2020.9.FOCUS20564.

${ }^{*}$ A.R. and N.A. contributed equally to this work. 
manpower for medical management of COVID. We discuss each of these topics in detail in light of the published literature and our experience.

\section{Reorganization of Infrastructure and Manpower}

A pertinent example of restructuring of manpower and infrastructure comes from Lombardy, Italy, an area heavily affected by the COVID-19 pandemic. ${ }^{8}$ Neurosurgeons in Lombardy employed a "hub-and-spoke" scheme wherein all urgent neurosurgical activity of the region was clustered among three centers (Niguarda, Brescia, and Varese, called emergency neurosurgical hubs). Apart from these three centers, only one other center (the Carlo Besta Neurological Institute in Milan, Italy) functioned as the regional centralizing neurosurgery hub for nondeferrable tumor cases. ${ }^{9}$ With the cooperation of neurosurgeons from "spoke" hospitals, the number of on-duty neurosurgeons in the "hub" hospitals doubled, and all neurosurgical units in the spoke hospitals became inactive within a week. ${ }^{8,9}$ This and the reduction of all elective surgery in the region was an effort to preserve ICU beds for COVID-19 patients. A similar model was employed in our city (New Delhi, India), where certain hospitals were designated as COVID-19 facilities so as to concentrate healthcare manpower and resources-ventilators, personal protective equipment (PPE), intensive care facilities, etc.-for optimal management of COVID-19 patients, without compromising the safety of non-COVID-19 patients. Along similar lines, our institute, having a bed capacity of $>3000$, designated two separate satellite centers, the National Cancer Institute and the Trauma Centre, as COVID-19 facilities. The centers have a capacity of $>800$ patients (National Cancer Institute) and $>200$ patients (Trauma Centre), with the former primarily for patients with mild symptoms and the latter for patients with moderate or severe symptoms requiring assistive ventilation and intensive monitoring. This setup ensured physical and spatial distancing of COVID-19 facilities from nonCOVID-19 facilities, reducing COVID-19 cross-infection and optimizing cost-effective utilization of PPE and hospital resources. A centralized database of the number of COVID-19 beds and ventilators available in our city enabled real-time tracking by using an app to streamline the processes of patient referral, testing, triage, and admission.

With the reduction or cessation of elective procedures, the need for doctors required for inpatient care decreased. Thus, in order to optimize resource utilization, Burke et al. recommended a "paired-coverage model" of resident physicians and healthcare providers (HCPs).$^{10}$ In this model, each individual hospital has three HCP groups: two teams that switch coverage on a 3-day cycle, and an alternate group that substitutes for any team member who shows signs of illness. In this way, if a team becomes contaminated, the other team will take over, and the alternates will fill the gap. Many other authors have recommended a similar model. ${ }^{11-13}$ We used a similar strategy in our department, in which we divided 40 residents and 25 faculty members into three teams, with distribution among the teams of neurosurgeons of various specialties so that each group had similar experience levels and expertise in each of the areas of vascular, trauma, neuro-oncology, spine, functional, and pediatric neurosurgery. Each team was on call for a week and then responsible for self-quarantining for the next 2 weeks. In cases in which more than $50 \%$ of any team was subjected to high-risk exposure to COVID-19-positive patients or staff, or became symptomatic, the next team would take over and so on. This enabled us to render neurosurgical care in our setting with maximum efficiency with approximately 100 neurosurgical beds at our disposal.

\section{Clinic Scheduling and the Role of Telemedicine}

During this COVID-19 pandemic, increasing numbers of hospitals and doctors have relied on teleconsultations for patient follow-ups, leading to decongestion of hospitals, timely treatment, and decreased exposure to COVID-19. Since March 2020, the telemedicine encounters at Johns Hopkins Hospital (Baltimore, MD) have increased 1000 -fold. ${ }^{14}$ Similarly, the number of clinic visits at Jackson Memorial Hospital (Miami, FL) has decreased by $80 \%$ since the shift to telemedicine. ${ }^{11}$ Most hospitals providing teleconsultation services have received positive feedback from both patients and providers. ${ }^{11,12,15}$ Similarly to the results reported for these two US hospitals, we had to resort to teleconsultations as a primary mode of outpatient consults during the nationwide lockdown in India. We observed that it is easier to assess and advise patients regarding routine postoperative checks, vascular pathology, and brain tumors. Other pathologies requiring subtle examination findings, such as peripheral nerve and spine pathologies, are more difficult to assess via telemedicine.

Other important issues that must be redressed to improve the practice of telemedicine include medicolegal and reimbursement procedures, interstate licensure, malpractice liability, and technological challenges. ${ }^{15}$ We have realized that these teleconsultation platforms were hugely underutilized and can also be used in the future for select groups of patients. Our neurosurgery center is a high-volume referral center, with a daily visit rate of almost 600 patients at our clinics. In accordance with the recommendations of our institute's hospital infection control committee (HICC), we formulated guidelines to streamline patient flow to ensure patient safety and minimize the exposure of HCPs without compromising patient care. In formulating these guidelines, we dealt with key issues that included strictly maintaining social distancing, minimizing patient stays in hospital premises, and providing adequate protection of staff by using appropriate designated PPE levels (Table 1) and frequent disinfection of surfaces and environments, having a separate area for consulting patients with respiratory symptoms, and performing thermal screening of all visitors at entrances.

\section{Surgical Scheduling \\ Triaging of Neurosurgical Procedures}

Globally, neurosurgeons reduced their frequency of performing elective neurosurgical procedures at the peak 
TABLE 1. HICC guidelines for the use of PPE in different hospital settings

\begin{tabular}{|c|c|c|}
\hline Target Personnel/Pts & Activity & PPE \\
\hline \multicolumn{3}{|l|}{ Designated COVID-19 areas } \\
\hline \multicolumn{3}{|l|}{ ICU } \\
\hline Healthcare workers (doctor/nurses/technicians) & AGP & Level III kit w/ face shield \\
\hline $\mathrm{SA} / \mathrm{HA}$ & Disinfection/pt shifting & Level III kit w/ heavy-duty gloves \& boots \\
\hline \multicolumn{3}{|l|}{ Ward } \\
\hline Healthcare workers (doctors/nurses/technicians) & Non-AGP & Level II kit w/ face shield for AGPs \\
\hline $\mathrm{SA} / \mathrm{HA}$ & Disinfection/pt shifting & Level II kit w/ heavy-duty gloves \& boots \\
\hline \multicolumn{3}{|l|}{ Emergency screening area } \\
\hline Healthcare workers (doctor/nurses) & Screening/sampling & Level II kit w/ face shield for AGPs \\
\hline $\mathrm{SA} / \mathrm{HA}$ & Disinfection/pt shifting & Level II kit w/ heavy-duty gloves \& boots \\
\hline \multicolumn{3}{|c|}{ Transport of COVID-19-suspected/-confirmed case in ambulance } \\
\hline \multicolumn{3}{|c|}{ Ambulance (healthcare workers traveling in pt compartment) } \\
\hline Healthcare workers (doctors/nurses) & Attending pt (direct contact $>15$ mins) & Level II kits \\
\hline $\mathrm{SA} / \mathrm{HA}$ & Disinfection/pt shifting & Level II kit w/ heavy-duty gloves \& boots \\
\hline Driver & No direct contact & N95 masks \\
\hline \multicolumn{3}{|l|}{ Designated non-COVID-19 areas } \\
\hline \multicolumn{3}{|l|}{ Emergency medicine } \\
\hline Healthcare workers (doctor/nurses/technicians) & Non-AGP & Level I kit; face shield for AGPs \\
\hline $\mathrm{SA} / \mathrm{HA}$ & Disinfection/pt shifting & Level I kit w/ heavy-duty gloves \\
\hline \multicolumn{3}{|l|}{ General out-pt/EHS out-pt } \\
\hline Healthcare workers (doctor/nurses) & Non-AGP & Level I kit \\
\hline $\mathrm{SA} / \mathrm{HA}$ & Disinfection & Level I kit w/ heavy-duty gloves \\
\hline \multicolumn{3}{|l|}{ General ward/private rooms } \\
\hline Healthcare workers (doctor/nurses) & Non-AGP & Level I kit; face shield (for AGPs) \\
\hline $\mathrm{SA} / \mathrm{HA}$ & Disinfection/pt shifting & Level I kit w/ heavy-duty gloves \\
\hline \multicolumn{3}{|l|}{ ICU } \\
\hline Healthcare workers (doctor/nurses/technicians) & AGP in non-COVID-19 area & Level II kit w/ face shield \\
\hline $\mathrm{SA} / \mathrm{HA}$ & Disinfection/pt shifting & Level II kit w/ heavy-duty gloves \& boots \\
\hline \multicolumn{3}{|l|}{ EHS dispensary } \\
\hline Pharmacist & Drug dispensing & N95 mask \\
\hline \multicolumn{3}{|l|}{ Laboratory personnel } \\
\hline Doctors/technicians & Dealing w/ respiratory samples & Level II kit \\
\hline \multicolumn{3}{|l|}{ Radiodiagnosis } \\
\hline Doctors/technicians & Non-AGP & N95 mask \\
\hline \multicolumn{3}{|l|}{ Administrative offices } \\
\hline All staff & No direct pt contact & N95 mask \\
\hline \multicolumn{3}{|l|}{ Confirmed/suspected COVID-19 case } \\
\hline $\mathrm{Pt}$ & Droplet prevention & Triple-layered mask \\
\hline
\end{tabular}

$\mathrm{AGP}=$ aerosol-generating procedure; $\mathrm{EHS}=$ employee health scheme; $\mathrm{HA}=$ hospital attendant; $\mathrm{pt}$ = patient; out-pt = outpatient; $\mathrm{SA}=$ sanitation attendant. Level I = gown-based PPE kit; gown + N95 mask + goggles + gloves. Level II = coverall (same material as gown)-based PPE kit; coverall + N95 + goggles + long shoe cover + gloves. Level III = coverall (Tyvec/Tychem/Kimberly Clark)-based PPE kit; coverall + N95 + goggles + long shoe cover + gloves .

of the pandemic to preserve supplies, PPE, blood products, and ICU beds and to minimize the exposure of HCPs to COVID-19.16,17 We reviewed the recommendations of multiple neurosurgical societies, and our experience also corroborates their plans to triage neurosurgical procedures to provide the best possible treatment.,3,6,10,18 The American College of Surgeons recommended that surgeons and hospitals consider postponing all elective surgeries until a decrease in new COVID-19 cases is achieved and the expanded healthcare infrastructure is able to support all cases. ${ }^{2}$ The European Association of Neurosurgical Societies recommends triage of neurosurgical cases using a tiered approach based on emergency status classification. ${ }^{3}$ Another noteworthy protocol is the Mount Sinai Neurosurgery Management algorithm, which has been designed while keeping in mind the challenges faced by hospitals 




FIG. 1. Stratification of neurosurgery cases and timing for emergency, semi-emergency, and elective surgical intervention based on risk to life, impending neurological impairment, pathology, and COVID-19 status. Specific conditions are likely to require the interventions listed as follows. Emergency surgery-head injury with large extradural/subdural hematoma/contusion, malignant middle cerebral artery infarct, large supratentorial/basal ganglia/posterior fossa bleed, aneurysmal subarachnoid hemorrhage, hydrocephalus, malignant brain tumor with impending herniation/bleed/significant mass effect, pituitary apoplexy, ruptured open neural tube defect, and intracranial abscess/subdural empyema. Semi-emergency surgery-cauda equina syndrome, large intracranial benign tumors (meningioma, schwannoma, giant pituitary adenoma, craniopharyngioma), large low-grade glioma with mass effect, unruptured intracranial aneurysm, posterior fossa tumors (medulloblastoma, ependymoma, etc.), spinal tumors with progressive myelopathy, and unstable spinal injury with neurological deficits. Elective surgery-benign small intracranial tumors (meningioma, schwannoma, pituitary adenoma, cavernoma, craniopharyngioma), congenital spinal or intracranial abnormalities, tethered cord syndrome, unruptured intracranial arteriovenous malformation and moyamoya disease, small low-grade glioma (asymptomatic or mildly symptomatic), degenerative spinal pathology, functional and epilepsy procedures, brachial plexus and peripheral nerve injuries and tumors, cranioplasty, and spinal tumors without myelopathy.

within the epicenter of the pandemic. ${ }^{19}$ Because New Delhi, India, was a hotspot for the COVID-19 pandemic at the time of this writing, we were withholding elective neurosurgical procedures and following a structured model to ascertain the urgency of neurosurgical intervention based on risk to life, impending neurological impairment, pathology, and COVID-19 status until we reached an inflection point in the COVID-19 case burden (Fig. 1). Our working model is somewhat similar to the "volumelimiting approach" described by Burke et al., which allows surgeons to triage their schedule and encourages maximal adaptability based on the disease "surge level" in their community. ${ }^{10}$ This dynamic system sets a limit on the number of cases as opposed to the type of cases depending on the surge level of the disease at any time point. Additionally, to facilitate effective communication among the surgical staff, Burke et al. proposed a checklist for neurosurgical cases based on the level of urgency and availability of operating rooms (ORs) and postoperative beds. In our emergency services, neurosurgical patients are subjected to triage and further management based on the urgency of the surgical intervention, presence of influenza-like illness (ILI) or severe acute respiratory infection (SARI)-related symptoms ${ }^{20}$ high-risk contact history with COVID-19-positive individuals, and patients living in COVID-19 containment zones/hotspots (Fig. 2). We keep suspected patients with pending COVID-19 investigation results in an isolation ward with negative-pressure ventilation (with six air changes per hour). Only essential HCPs are provided access to this area. Educating HCPs about appropriate PPE donning/doffing techniques with bilingual checklist compliance (Tables 2-4) is paramount for safe clinical practice..$^{21,22}$

\section{Preoperative Evaluation, Diagnostic Testing, and Decision Making}

Chinese neurosurgeons recommend a detailed clinical screening along with pulmonary $\mathrm{CT}$ and real-time reverse transcription-polymerase chain reaction (RT-PCR) studies for all patients prior to hospitalization for nonemergency cases. ${ }^{23}$ The Indian Council of Medical Research 


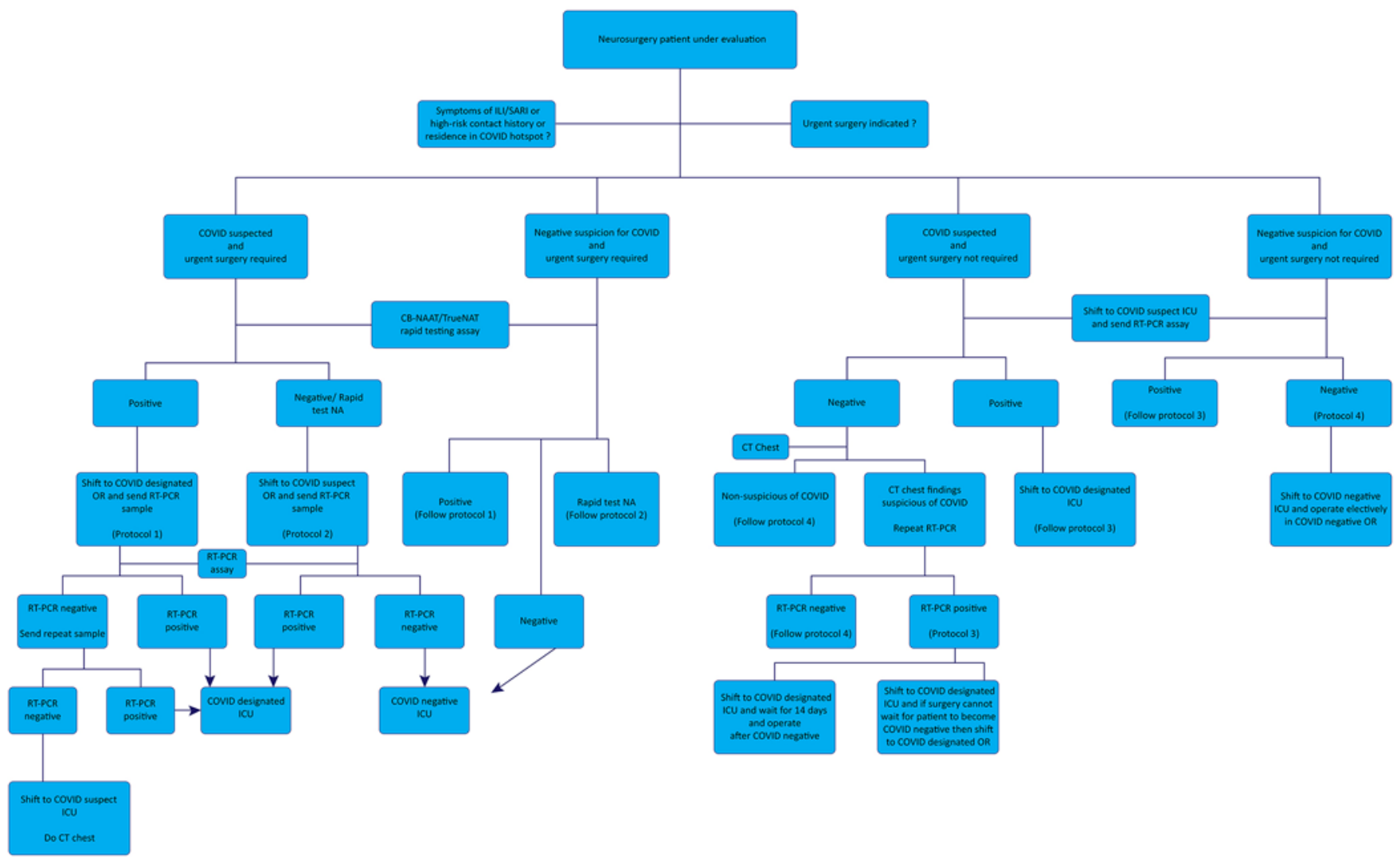

FIG. 2. Algorithm for neurosurgery patient triage from emergency services. NA = not available.

(ICMR) has issued guidelines for a testing strategy for COVID-19 in India. The latest version mandates testing of all symptomatic patients, their direct and high-risk contacts, and all hospitalized patients who develop ILI/ SARI symptoms. ${ }^{24}$ Most of the eminent centers around the world and many prominent surgical societies recommend mandatory preoperative testing of patients (Table 5) (https://en.wikipedia.org/w/index.php?title=COVID-19_ pandemic\&oldid=962494289)..$^{5-9,11,19,23,25-37}$ The ICMR has not yet mandated testing for all hospitalized patients because of resource constraints. However, if the facilities are available, then we recommend testing of all hospitalized patients and patients for whom elective/semi-emergency procedures are planned. There is a growing body of evidence in favor of this policy because surgery in patients with COVID-19 who are asymptomatic or presymptomatic leads to cross-infection and possible hazardous outcomes. ${ }^{38-43}$ In our center, until recently, real-time RT-PCR (the gold standard test) was the only diagnostic modality available. More recently, kits for cartridge-based nucleic acid amplification tests (CB-NAATs) and chip-based PCR assays (TrueNAT) have been made available and are being judiciously used to rapidly screen most of the emergency cases for which we cannot await the results of real-time RT-PCR. Some authors recommend revision of hospital protocols to delimit a precise route for the transfer of patients with suspected and confirmed cases in order to avoid cross-infection of other patients and unprotected personnel..$^{23,44}$ This may be done by "cohorting," sepa-
TABLE 2. Bilingual checklist for donning and doffing of PPE used at our hospital/पीपीई डॉनf ग और डॉफ़ा ग के लए जाँच सूची

1. Name of staff member/कर मचारी का नाम:

2. Name of observer/पर यवेक षक का नाम:

3. Date/दनिांक:

Note:

1. Get into scrubs or comfortable clothes, remove jewelry, \& ensure you have had water \& food, visited washrooms, etc., as the residents \& nurses are expected to stay inside for at least 6 hrs

2. The observer needs to be in PPE when observing doffing

3. Two chairs should be placed in doffing area labeled "DIRTY" \& "CLEAN"

4. Check all PPE before starting donning नोट:

1. स क रब या आरामदायक कपड 'पहने, आभषण नकिलें, सुनशि चति करें का आपने पानी पयिा है, खाना खाया है और वाशर म का इस ते माल कयि है, क यो करिे सडि ट स और नर सों से कम से कम 6 घंटे तक पीपीई पहने रहने की उम मीद की जाती है।

2. प रेक षक को डॉना ग का अवलोकन करते समय पीपीई में होना चोहिए।

3. दो कुर सयीं को 'गंदी' और 'स, वच् छ' ले बल करे और इन हैं डॉफ़ी गे वाले क षेत र में रखा जाना चाहएि

4. डॉफ़ि ग शुरू करने से पहले सभी पीपीई की जांच करें। 
TABLE 3. Checklist for coverall-based donning/डॉना ग के लए जाँच सूची

\begin{tabular}{|c|c|c|}
\hline $\begin{array}{l}\text { Step No. } \\
\text { क र. सं }\end{array}$ & Procedure/कार, यवधि & $\begin{array}{l}\text { Yes/No } \\
\text { हा } / \text { ना }\end{array}$ \\
\hline 1 & $\begin{array}{l}\text { Wash hands w/ soap \& water/साबुन और पानी से } \\
\text { हाथ धोए }\end{array}$ & \\
\hline 2 & $\begin{array}{l}\text { Don 1st pair of gloves/दस, ताने की पहली जोड. } \uparrow \\
\text { पहने }\end{array}$ & \\
\hline 3 & Don coverall/कवरॉल पहनें & \\
\hline 4 & Don shoe cover/ज तों के कवर पहनें & \\
\hline 5 & $\begin{array}{l}\text { Don mask/respirator (check for any leaks)/मास क/ } \\
\text { श वासयंत् र पहनें (इनमें कसी भी लीक के } \\
\text { लएि जांच करें) }\end{array}$ & \\
\hline 6 & $\begin{array}{l}\text { Don goggles/face shield/गॉगल, स/फे स शील, ड } \\
\text { पहनें }\end{array}$ & \\
\hline 7 & Don hood/हुड पहनें & \\
\hline 8 & $\begin{array}{l}\text { Don 2nd pair of gloves/दस, ताने की दूसरी जोड. . } \\
\text { पहने }\end{array}$ & \\
\hline 9 & $\begin{array}{l}\text { Gown fitness check (ask buddy to help)/गाउन } \\
\text { फटिने स की जांच करें (मदद के लएि साथी से } \\
\text { कहें) }\end{array}$ & \\
\hline
\end{tabular}

rating suspected COVID-19 patients by using dedicated wards, ICUs, elevators, and corridors and avoiding buffer zones such as recovery rooms. ${ }^{2,23,44,45}$

Similarly, we created a designated ICU to care for patients in whom COVID-19 was suspected but not confirmed, until their testing reports came back. To streamline the movement of patients through the COVID-19-suspect ICU, separate entry and exit areas were earmarked along with their respective PPE donning and doffing areas. Personnel were required to use a dedicated stretcher with disposable protection that could be disinfected well after use. ${ }^{44,45} \mathrm{In}$ addition, the residents and staff on duty in the COVID-19-suspect ICU worked in 6-hour shifts wearing optimal level II PPE including a face shield (Table 1). Once the test results were known, patients were shifted accordingly to the COVID-19-designated ICU facility or the COVID-19-negative ICU. This method of providing an ICU for patients suspected to have COVID-19 helps to streamline patient care and avoid unnecessary delays in treatment allocation as well as allaying apprehensions among HCPs about providing optimal patient care, because the same precautions are taken as for the COVID-19-positive ICU. For emergency surgeries, we try to get CB-NAAT/ TrueNAT assays done and triage the patients accordingly (Fig. 2). In emergency cases for which the results are still pending or are unavailable, patients are taken directly to the COVID-19-suspect OR with negative-pressure ventilation with HEPA filtration. Adequate precautions akin to those used in the COVID-19 OR are taken in the form of appropriate PPE donning/doffing, use of appropriate PPE level, disinfectant use for surfaces, etc., by all OR staff to ensure minimal risk of cross-infection to HCPs. For semiemergency cases, real-time RT-PCR is the preferred diag-
TABLE 4. Checklist for PPE doffing/डॉफ़ि ग के लए जाँच सूची

\begin{tabular}{|c|c|c|}
\hline $\begin{array}{l}\text { Step No. } \\
\text { क र.सं. }\end{array}$ & Procedure/कार्, यवधि & $\begin{array}{l}\text { Yes/No } \\
\text { हाँ/ना }\end{array}$ \\
\hline 1 & $\begin{array}{l}\text { Check for any leak or soiling in PPE before doffing } \\
\text { (disinfect site if contaminated)/डॉफ़ ग से पहले } \\
\text { पीपीई में कसि भी रसिव या सोइला ग की जां च } \\
\text { करें (साइट को डसिइंफेक ट करें, अगर दूषति है") }\end{array}$ & \\
\hline 2 & $\begin{array}{l}\text { Disinfect the hands while wearing gloves (similar } \\
\text { to hand hygiene procedure)/ } \\
\text { दस तान पहनत समय हाथों को डसिइंफे क ट करें } \\
\text { (हाथ की स वच छता- प रक रयि के समान) }\end{array}$ & \\
\hline 3 & $\begin{array}{l}\text { Remove shoe covers only by touching the outer } \\
\text { surface (by sitting on DIRTY chair)/ज तों के कवर } \\
\text { को के वल बाहरी सतह छूते हुए नकिलें (गंदी } \\
\text { कुर सी पर ब"ठकर) }\end{array}$ & \\
\hline 4 & Perform hand hygiene/हाथों को साफ़ करें & \\
\hline 5 & Remove outer gloves/बाहरी दस, ताने नकिलें & \\
\hline 6 & Perform hand hygiene/हाथों को साफ़ करें & \\
\hline 7 & Remove hood/हुड नकिलें & \\
\hline 8 & Perform hand hygiene/हाथों को साफ़ करें & \\
\hline 9 & Remove coverall/कवरॉल हटा दें & \\
\hline 10 & Perform hand hygiene/हाथों को साफ़ करें & \\
\hline 11 & $\begin{array}{l}\text { Remove goggles/face shield/गॉगल, स/फे स } \\
\text { शील, ड नकिले }\end{array}$ & \\
\hline 12 & Perform hand hygiene/हाथों को साफ़ करें & \\
\hline 13 & $\begin{array}{l}\text { Remove 2nd pair of gloves/दस, ताने की दूसरी } \\
\text { जोड . न नकिलें }\end{array}$ & \\
\hline 14 & Perform hand hygiene/हाथों को साफ़ करें & \\
\hline 15 & $\begin{array}{l}\text { Don new pair of gloves/दस, तान की नई जोड . } \\
\text { पहन }\end{array}$ & \\
\hline 16 & $\begin{array}{l}\text { Remove mask (do not touch front of mask, handle } \\
\text { w/ slings/bands)/मास, क हटा दें (मास क को } \\
\text { सामने से स, पर श श करें, स, ला ग/बैंड के साथ } \\
\text { संभालें) }\end{array}$ & \\
\hline 17 & Perform hand hygiene/हाथों को साफ़ करें & \\
\hline 18 & $\begin{array}{l}\text { Clean shoes w/ alcohol swabs (sitting on CLEAN } \\
\text { chair)/अल, कोहल स, वैब से ज ते साफ करें } \\
\text { (स, वच, छ, कुर, सी पर ब"ठकर) }\end{array}$ & \\
\hline 19 & $\begin{array}{l}\text { Remove last pair of gloves \& perform hand } \\
\text { hygiene/दस ताने की अंतमि जोड. } \uparrow \text { को हटा दें और } \\
\text { हाथों को साफ़ करें }\end{array}$ & \\
\hline
\end{tabular}

All PPE to be discarded in red bag. This red bag to be placed inside another red bag and sent for treatment (double bagging)/नोट: सभी पीपीई को लाल बै ग में छोड़ दयिा जाना चाहएि। इस लाल बैग को दूसर लाल बैग के अंदर रखा जाएगा और प् रशोधन के लए भे जा जाएगा ("डबल बे गा ग")।

nostic tool, preferably done twice ( 1 and 5 days before surgery), depending on the available resources. If any clinical symptoms pertaining to ILI or SARI develop in the interim period before surgery, the test may be repeated along with a chest $\mathrm{CT}$ scan to look for any corroborative radiological findings of COVID-19.

It is recommended that surgical procedures be deferred 
TABLE 5. Literature review of recommendations on preoperative testing

\begin{tabular}{|c|c|c|c|c|}
\hline Authors \& Year & $\begin{array}{l}\text { Country/Region or } \\
\text { US State }\end{array}$ & Institute & $\begin{array}{l}\text { Confirmed Cases } \\
\text { (country, region, } \\
\text { or US state) }\end{array}$ & Preop COVID-19 Testing Recommendation \\
\hline Boffa et al., $2020^{25}$ & US/CT & Yale & $44,994(\mathrm{CT})$ & $\begin{array}{l}\text { Pts should be tested w/in } 24 \text { hrs preop \& screened preop } \\
\text { morning for Sx \& temperature }\end{array}$ \\
\hline Kessler et al., $2020^{19}$ & US/NY & $\begin{array}{c}\text { Mount Sinai } \\
\text { Hospital }\end{array}$ & $387,402(N Y)$ & $\begin{array}{l}\text { Pts generally considered COVID-19 positive until proven oth- } \\
\text { erwise; as available, multiple rounds of testing sent ASAP }\end{array}$ \\
\hline Daci et al., $2020^{26}$ & US/MA & $\begin{array}{l}\text { UMass } \\
\text { Memorial } \\
\text { Health Care, } \\
\text { Worcester }\end{array}$ & $105,395(\mathrm{MA})$ & Preop testing of all op pts \\
\hline Eichberg et al., $2020^{11}$ & US/FL & $\begin{array}{l}\text { Jackson } \\
\text { Memorial, } \\
\text { Miami }\end{array}$ & $73,544(\mathrm{FL})$ & $\begin{array}{l}\text { Preop screening of all op cases; impose 14-day delay if testing } \\
\text { not available }\end{array}$ \\
\hline Zacharia et al., $2020^{27}$ & $\begin{array}{l}\text { US/multicenter } \\
\text { recommendation } \\
\text { based on expert } \\
\text { opinion }\end{array}$ & & & $\begin{array}{l}\text { Emergency: assume COVID-19 positive; urgent: preop test if } \\
\text { available as close as possible to op; quarantine until result } \\
\text { negative; if test unavailable, assume COVID-19 positive; } \\
\text { semi-urgent: test if available, if unavailable self-quarantine } \\
14 \text { days }\end{array}$ \\
\hline $\begin{array}{l}\text { Turri-Zanoni et al., } \\
2020^{28}\end{array}$ & Italy/Lombardy & $\begin{array}{l}\text { University of } \\
\text { Insubria, } \\
\text { Varese }\end{array}$ & $\begin{array}{l}\text { 91,204 (Lom- } \\
\text { bardy) }\end{array}$ & $\begin{array}{l}\text { Mandatory definition of pt COVID-19 status even if asymp- } \\
\text { tomatic: nasopharyngeal swabs complemented w/ chest } \\
\text { imaging, immunological antibody determination, \& saliva } \\
\text { viral load quantification }\end{array}$ \\
\hline $\begin{array}{l}\text { Cenzato et al., } 2020^{8} \& \\
\text { Perin et al., } 2020^{9}\end{array}$ & Italy/Lombardy & $\begin{array}{l}\text { Carlo Besta } \\
\text { Neurological } \\
\text { Institute, } \\
\text { Milan }\end{array}$ & $\begin{array}{l}\text { 91,204 (Lom- } \\
\text { bardy) }\end{array}$ & $\begin{array}{l}\text { All admitted pts: thorough screening w/ body temperature, } \mathrm{O}_{2} \\
\text { saturation, CRP, transaminases, CBC, chest radiography, } \\
\text { pharyngeal SARS-CoV-2 swab, \& thorough clinical history; } \\
\text { emphasis on ensuring hospital "COVID-19 free" per "hub- } \\
\text { \&-spoke" policy }\end{array}$ \\
\hline $\begin{array}{l}\text { Molliqaj \& Schaller, } \\
2020^{29}\end{array}$ & Switzerland/Geneva & $\begin{array}{l}\text { Geneva } \\
\text { University } \\
\text { Medical } \\
\text { Center }\end{array}$ & $\begin{array}{l}31,094 \text { (Switzer- } \\
\text { land); } 5142 \\
\text { (Geneva) }\end{array}$ & $\begin{array}{l}\text { Emergency cases: deemed positive; urgent cases: op after } \\
\text { testing }\end{array}$ \\
\hline Tan et al., $2020^{23}$ & China/Hubei & $\begin{array}{l}\text { Tongji Hospital, } \\
\text { Wuhan }\end{array}$ & 68,135 (Hubei) & $\begin{array}{l}\text { Clinical screening in out-pt department; pulmonary CT \& } \\
\text { nucleic acid sequencing of throat swab recommended for } \\
\text { preliminary COVID-19 diagnosis prehospitalization; direct } \\
\text { emergency op performed for life-threating pt condition }\end{array}$ \\
\hline Chibbaro et al., $2020^{30}$ & France/Alsace & $\begin{array}{l}\text { Strasbourg } \\
\text { University } \\
\text { Hospital, } \\
\text { Alsace }\end{array}$ & 157,000 (France) & $\begin{array}{l}\text { Emergency: no need for swab; deferrable: management } \\
\text { postswab; op deferrable } \geq 48 \text { hrs, \& expedited w/in } 7-15 \\
\text { days; elective: management postswab; op rescheduled w/ } \\
\text { in } 2-4 \text { mos }\end{array}$ \\
\hline Kolias et al., $2020^{31}$ & UK/Cambridge & $\begin{array}{l}\text { Addenbrooke's } \\
\text { Hospital, } \\
\text { Cambridge }\end{array}$ & 294,000 (UK) & $\begin{array}{l}\text { Pt Sx screened } 1 \text { wk prior \& asked to self-isolate; } 2 \text { nasopha- } \\
\text { ryngeal swabs preop (day 4-5 \& day 2); pts w/ } 2 \text { negative } \\
\text { swabs admitted on day of op \& screened again for any } \\
\text { COVID-19 Sx }\end{array}$ \\
\hline $\begin{array}{l}\text { COVIDSurg Collabora- } \\
\text { tive, } 2020^{32}\end{array}$ & South Korea/Seoul & $\begin{array}{r}\text { Yonsei Univer- } \\
\text { sity College } \\
\text { of Medicine }\end{array}$ & $\begin{array}{l}\text { 12,085 (South } \\
\text { Korea) }\end{array}$ & $\begin{array}{l}\text { All pts screened for respiratory Sx \& tested for COVID-19 } \\
\text { preop }\end{array}$ \\
\hline Oudrhiri et al., $2020^{33}$ & Morocco/Rabat & $\begin{array}{l}\text { WFNS Rabat } \\
\text { Reference } \\
\text { Centre ONO } \\
\text { Hospital }\end{array}$ & 8734 (Morocco) & $\begin{array}{l}\text { Initial assessment w/ pulmonary CT; COVID-19 testing of } \\
\text { suspected cases }\end{array}$ \\
\hline Lo et al., $2020^{34}$ & Singapore & $\begin{array}{l}\text { Singapore } \\
\text { General } \\
\text { Hospital }\end{array}$ & $\begin{array}{l}40,604 \text { (Singa- } \\
\text { pore) }\end{array}$ & $\begin{array}{l}\text { All pts: clinical screening \& exposure history questionnaire, } \\
\text { preop chest radiography; preop swab for all elective high- } \\
\text { risk op pts (transgressing upper airways) }\end{array}$ \\
\hline
\end{tabular}


» CONTINUED FROM PAGE 7

TABLE 5. Literature review of recommendations on preoperative testing

\begin{tabular}{|c|c|c|c|c|}
\hline Authors \& Year & $\begin{array}{l}\text { Country/Region or } \\
\text { US State }\end{array}$ & Institute & $\begin{array}{l}\text { Confirmed Cases } \\
\text { (country, region, } \\
\text { or US state) }\end{array}$ & Preop COVID-19 Testing Recommendation \\
\hline $\begin{array}{l}\text { Society of British Neuro- } \\
\text { logical Surgeons, } 2020^{7}\end{array}$ & $\begin{array}{l}\text { Society of British } \\
\text { Neurological } \\
\text { Surgeons }\end{array}$ & & & Preop testing should be employed when available \\
\hline $\begin{array}{l}\text { Ramakrishna et al., } \\
2020^{6}\end{array}$ & $\begin{array}{l}\text { AANS/CNS Tumor } \\
\text { Section \& Society } \\
\text { for Neuro-Oncol- } \\
\text { ogy }\end{array}$ & & & $\begin{array}{l}\text { When possible, pts should receive COVID-19 testing on day } \\
\text { of op }\end{array}$ \\
\hline $\begin{array}{l}\text { American Society of An- } \\
\text { esthesiologists, } 2020^{35}\end{array}$ & $\begin{array}{l}\text { American Society } \\
\text { of Anesthesiolo- } \\
\text { gists \& Anesthesia } \\
\text { Patient Safety } \\
\text { Foundation }\end{array}$ & & & $\begin{array}{l}\text { All pts should be screened for Sx prior to presenting to } \\
\text { healthcare facility; pts reporting Sx should be referred for } \\
\text { additional evaluation; nonemergency pts should undergo } \\
\text { NAAT (w/ PCR) preop }\end{array}$ \\
\hline Castelnuovo et al., $2020^{5}$ & $\begin{array}{l}\text { Italian Skull Base } \\
\text { Society }\end{array}$ & & & $\begin{array}{l}\text { All nonemergncy preop pts: mandatory testing } w / \geq 2 \text { tests, } \\
\text { repeated at } 2-4 \text { days, to minimize false negatives; last test } \\
\text { must be w/in } 48 \text { hrs preop }\end{array}$ \\
\hline Muhammad et al., $2020^{36}$ & $\begin{array}{l}\text { Recommendations } \\
\text { based on expert } \\
\text { opinion of } 4 \text { neu- } \\
\text { rosurgeons known } \\
\text { worldwide from } 3 \\
\text { different continents } \\
\text { (US/Europe/Asia) }\end{array}$ & & & $\begin{array}{l}\text { Management based on preop testing, } 2 \text { w/in } 24 \text { hrs or chest } \\
\text { CT }\end{array}$ \\
\hline $\begin{array}{l}\text { COVID-19 pan- } \\
\text { demic in India (https:// } \\
\text { en.wikipedia.org/w/index. } \\
\text { php?title=COVID-19_ } \\
\text { pandemic_in_ } \\
\text { India\&oldid=966630532) }\end{array}$ & India/New Delhi & $\begin{array}{l}\text { All India } \\
\text { Institute of } \\
\text { Medical Sci- } \\
\text { ences, New } \\
\text { Delhi }\end{array}$ & 36,824 (Delhi) & $\begin{array}{l}\text { Mandatory testing of all pts hospitalized for neurosurgi- } \\
\text { cal intervention, endovascular treatment; pts requiring } \\
\text { conservative management: history of Sx related to ILI or } \\
\text { SARI, contacts, residence in COVID-19 containment zones } \\
\text { warrant testing. Emergency op: CB-NAAT/TrueNAT rapid } \\
\text { assays; semi-emergency op: real-time RT-PCR; pts w/ Sx: } \\
\text { real-time RT-PCR \& chest CT }\end{array}$ \\
\hline
\end{tabular}

$\mathrm{ASAP}=$ as soon as possible; $\mathrm{CBC}=$ complete blood count; $\mathrm{CRP}=\mathrm{C}$-reactive protein; ONO = Oto-Neuro-Ophtalmology; $\mathrm{Sx}=$ symptoms; WFNS = World Federation of Neurosurgical Societies.

for a patient who is COVID-19 positive until their test is negative. If the procedure is deemed strictly necessary for patient survival, then the lifesaving surgery may be done, with the surgical team and the entire OR staff wearing enhanced level III PPE, not only for the entire duration of surgery but also for the whole of the patient's stay in the OR. For COVID-19-negative patients, optimal individual protection standards should be maintained in consideration of the significantly high rates of false-negative results of the diagnostic tests currently used. .,23,36,44 $^{2}$

\section{Patient Data}

For the purpose of illustration of data, we have divided the COVID-19 period in our setup into 5 phases based on the timelines of the first 5 nationwide lockdown periods (approximately 14 weeks each) (https://en.wikipedia.org/w/ index.php?title=COVID-19_pandemic_lockdown_in_India \&oldid $=966620248$ ), and compared our data with the COVID-19 burden in the community (Table 6) (https:// en.wikipedia.org/w/index.php?title=COVID-19_pandemic
_in_Delhi\&oldid=966360865; https://en.wikipedia.org/w/ index.php?title=COVID-19_pandemic_in_India\&oldid= 966630532). Among the 351 inpatients we treated during this time period, 42 patients turned out to be COVID-19 positive (approximately 12\%) during the emergency triage. Overall, 170 patients underwent surgery $(21.2 \%$ suspect/ indeterminate COVID-19 cases and 78.8\% COVID-19negative cases), including 3 asymptomatic patients who turned out to be COVID-19 positive after surgery (cumulative incidence of delayed COVID-19 positivity $3 / 170=1.76$ per 100 operated asymptomatic neurosurgery patients).

\section{Intraoperative Management}

As a protocol, our department has made it mandatory to obtain a separate COVID-19 consent for each operative patient, as there is risk of acquiring nosocomial COVID-19 infection in otherwise noninfected patients, despite taking adequate precautions. Similar to prior recommendations, we use dedicated negative-pressure ORs with a preestab- 
TABLE 6. COVID-19 pandemic nationwide lockdown phases and neurosurgical case distribution at our center during 2020

\begin{tabular}{|c|c|c|c|c|c|c|}
\hline & $\begin{array}{c}\text { Phase I (March } \\
\text { 25-April 14) }\end{array}$ & $\begin{array}{c}\text { Phase II (April } \\
\text { 15-May 3) }\end{array}$ & $\begin{array}{c}\text { Phase III } \\
\text { (May 4-17) }\end{array}$ & $\begin{array}{c}\text { Phase IV } \\
\text { (May 18-31) }\end{array}$ & $\begin{array}{c}\text { Phase V } \\
\text { (June 1-30) }\end{array}$ & Total \\
\hline $\begin{array}{l}\text { No. of confirmed COVID-19 cases in India (https:// } \\
\text { en.wikipedia.org/w/index.php?title=COVID-19_ } \\
\text { pandemic_in_India\&oldid=966630532) }\end{array}$ & 10,296 & 29,448 & 50,664 & 91,216 & 384,697 & 566,321 \\
\hline Average cases per day in India & 490 & 1550 & 3619 & 6515 & 12,823 & \\
\hline $\begin{array}{l}\text { No. of confirmed COVID-19 cases in Delhi (https:// } \\
\text { en.wikipedia.org/w/index.php?title=COVID-19_ } \\
\text { pandemic_in_Delhi\&oldid=966360865) }\end{array}$ & 1530 & 2988 & 5206 & 10,089 & 67,516 & 87,329 \\
\hline Average cases per day in Delhi & 73 & 157 & 372 & 721 & 2251 & \\
\hline New admissions & $36+44^{*}+56 \dagger$ & 35 & 49 & 39 & 92 & 351 \\
\hline Total COVID-19-positive pts & 5 & 4 & 7 & 7 & 19 & 42 \\
\hline Pts discharged & 61 & 31 & 27 & 23 & 79 & 221 \\
\hline Total op pts & 25 & 26 & 35 & 24 & 60 & 170 \\
\hline COVID-19-positive cases preop & 0 & 0 & 0 & 0 & 0 & 0 \\
\hline COVID-19-indeterminate/-suspect cases preop & 12 & 8 & 6 & $4 \ddagger$ & 6 & 36 \\
\hline COVID-19-negative cases preop & 13 & 18 & 29 & $20 \S$ & $54 \S$ & 134 \\
\hline Overall mortality (\%) & $10(7.35)$ & $3(8.57)$ & $6(12.24)$ & $6(15.38)$ & $14(15.21)$ & $39 / 351(11.11)$ \\
\hline Op mortality (\%) & $2(8.0)$ & $1(3.8)$ & $3(8.57)$ & $2(8.33)$ & $5(8.33)$ & $13 / 170(7.64)$ \\
\hline
\end{tabular}

* Patients transferred to the main neurosurgical facility when the trauma center was repurposed for care of COVID-19 patients.

† Patients already admitted in the main COVID-19-negative facility on March 25, 2020.

$\ddagger$ One patient with severe traumatic brain injury (E1VtM2 at admission) who was COVID-19 indeterminate prior to surgery turned out to be positive after surgery. This patient died due to raised intracranial pressure. The incidence of COVID-19 positivity was determined to be 2.78 per 100 asymptomatic surgery patients suspected to have COVID-19.

$\S$ Two patients, one with a right basal ganglia hypertensive bleed and one with an anterior communicating artery aneurysm with a subarachnoid hemorrhage, who were negative for the SARS-CoV-2 virus prior to surgery (false-negative testing possibly due to inherent RT-PCR test limitations/viral incubation period/improper tissue sampling) turned out to be COVID-19 positive after surgery during re-testing (one patient during active surveillance for high-risk contact with a COVID-19-positive person in the ICU and the other patient due to development of symptoms pertaining to SARI). Both patients had good outcomes at discharge. The incidence of delayed COVID-19 positivity was 1.49 per 100 operated asymptomatic COVID-19-negative patients.

lished allocated run for suspected and negative COVID-19 patients. ${ }^{5,23,44}$ Literature consistently recommends minimizing the operating staff to preserve PPE and reduce exposures. ${ }^{4-6,36}$ Many hospitals have developed protocols to intubate patients with confirmed COVID-19 infections outside of the OR or to have all nonessential personnel leave until the patient has been intubated for $30 \mathrm{~min}-$ utes. ${ }^{13,18,27,45}$ Although we do not have designated areas for intubation outside the ORs, once the timeout is done and the WHO checklist for surgery is signed, we stagger the reentry of the neurosurgical team for at least 20 minutes postintubation to minimize the exposure to aerosolized virus. Separate donning and doffing areas with their respective entry and exit gates (if possible) are recommended in ORs to help streamline staff movement and reduce spillage of contaminated PPE, surgical gowns, masks, gloves, etc., from doffing to clean areas near the scrubbing and donning station. Air conditioning (AC) ducts in our ORs are being designed to have ultraviolet germicidal irradiation installed as part of the infrastructure development drive in our institute, to further reduce the risk of infection spread along AC ducts from recirculated air.

Despite the lack of robust clinical data at present, there is a global consensus that proximity of nasal, oral, and respiratory mucosa to the access areas in skull base surgery subjects neurosurgeons to a higher risk of acquir- ing COVID-19 infection during surgical procedures. ${ }^{1,5,7,34}$ Hence, adequate precautions and diagnostic testing are mandatory to reduce the risk of cross-infection. Endonasal procedures pose a significant risk to operating staff, given the high viral load in the upper airway of infected patients. 727,46 Use of debriders and drills within the nasal cavity produces droplet aerosols which may be highly contagious. The American Association of OtolaryngologyHead and Neck Surgery (AAO-HNS) recommends deferring endoscopic endonasal procedures unless emergent or until preoperative COVID-19 testing can be performed. ${ }^{1}$ In patients for whom surgery cannot be deferred, consideration should be given to alternatives to endoscopic surgery: craniotomy (if the frontal sinuses can be avoided) or microscope-based transsphenoidal surgery (submucosal approach and entry to the sella using non-drill techniques). ${ }^{7}$ Utmost care should be taken with nasal secretions, and powered air-purifying respirators should be worn during the procedure. ${ }^{34,36}$ Hence, minimal use of high-speed drills, minimal irrigation while drilling to reduce aerosol generation, avoidance of opening the frontal sinuses and mastoid air cells during transcranial surgery (if feasible), wearing of face shields to reduce direct exposure of conjunctiva to generated aerosols and droplets, preferable use of rongeurs and nibblers in place of drills (wherever feasible), and use of novel techniques are recommended to further reduce 




FIG. 3. Novel conceptualized microscope-mounted customized drape to reduce the exposure of aerosolized virus particles to the operating surgeon (photographs taken by Dr. Vivek Tandon).

direct contact between the neurosurgeons and operative field aerosols. We have conceptualized the use of a novel microscope-mounted plastic drape covering the operative field (Fig. 3), with built-in slots to insert instruments and operate. Adherence to these basic surgical principles and protocols has ensured safe neurosurgical practice in our department as of the time of this writing.

\section{Postoperative Care}

Strict decontamination of the OR is required after surgery. In our setup, the ORs undergo fumigation after each case in COVID-19-suspected and COVID-19-positive patients to ensure minimal risk of cross-infection to subsequent cases. Hospital infectious disease departments may be requested to intermittently perform tests in the OR to check for the presence of viruses. ${ }^{44}$ The American Association of Neurological Surgeons/Congress of Neurological Surgeons Tumor Section and Society for Neuro-Oncology recommend shifting patients after simple craniotomies to stepdown units or wards instead of ICUs and to make efforts for early discharge of patients to their homes rather than rehabilitation centers. ${ }^{6,11,27}$ Additionally, it is recommended that family visits be limited to a strict minimum..$^{11,44}$

\section{Revamp of Neurosurgical Education}

The suspension of elective surgeries at most hospitals has drastically changed the daily schedules of neurosurgical residents, who now find themselves with more free and unstructured time. Maintenance of essential standard medical and surgical education among residents during pandemic conditions is paramount. To ensure that residents have access to ongoing learning opportunities, the department of neurosurgery at the Geneva University Medical Center has introduced daily microsurgery courses in training rooms at the Swiss Foundation for Innovation and Training in Surgery, following adequate social distancing norms. ${ }^{29}$ In most hospitals, all in-person conferences such as grand rounds, resident education conferences, and multidisciplinary board meetings have been replaced by video teleconferences and virtual group interactions.11,12,17,47 There is a substantial current trend for online webinars, supported by various neurosurgical societies, which allows participants from different geographical locations to learn from the experts, ask questions, and occasionally respond to polls. In our department, we have also resorted to online journal clubs, seminars, and other academic activities via webinar portals to ensure resident involvement and active learning. We also have recently conducted a live online cadaveric course for cavernous sinus dissection presented by an international faculty as part of our continuing medical education initiative. Furthermore, we envision the setup of live transmission from our ORs to our trainees via secure web portals in the near future.

\section{Structured Reallocation of Manpower to COVID-19-Designated Areas}

A COVID-19 task force (Human Resource Committee) was established under the director of our institute when the global COVID-19 pandemic was declared by the WHO. The purpose of this task force is to optimize and adequately manage the workforce (including residents and faculty) for COVID-19-designated areas to prevent the early burnout of medical personnel and the eventuality of a staff shortage, depending on the number of admitted positive patients and suspected outpatients coming to screening clinics. The departments were divided into multiple categories, primarily based on their degree of current engagement in managing critically ill patients, ranging from clinical departments to pre-/paraclinical departments. Correspondingly, treatment facilities for COVID-19-designated areas were categorized into various levels based on the characteristics of patients being treated, and the management of decision making, which will need to be implemented. Accordingly, a template was created to allocate different categories of residents and faculty to their appropriate levels of COVID-19-designated facility (depending on their clinical exposure to ICUs, high-dependency units, and critically ill patients), if the need arises (Fig. 4). At present, our institute is providing care to more than 750 COVID-19-positive cases overall, including approximately 150 patients requiring assistive ventilation or oxygenation. In addition, hundreds of patients are coming to screening areas daily for COVID-19-suspected cases, with an anticipated increase in these numbers as the pandemic unfolds. Hence, many departments, including neurosurgery, have deployed their personnel in the COVID-19-designated areas. The training module before the deployment includes online video sessions and live demonstrations of correct donning and doffing techniques ${ }^{21,22}$ by the HICC and training for intubation and resuscitation measures by a team appointed by the team leader faculty members of the COVID-19 task force. To ensure that a uniform level of training is devised and delivered, close coordination is paramount between the respective faculty in charge of COVID-19-designated facilities and the nodal officers of the HICC and COVID-19 task force. 


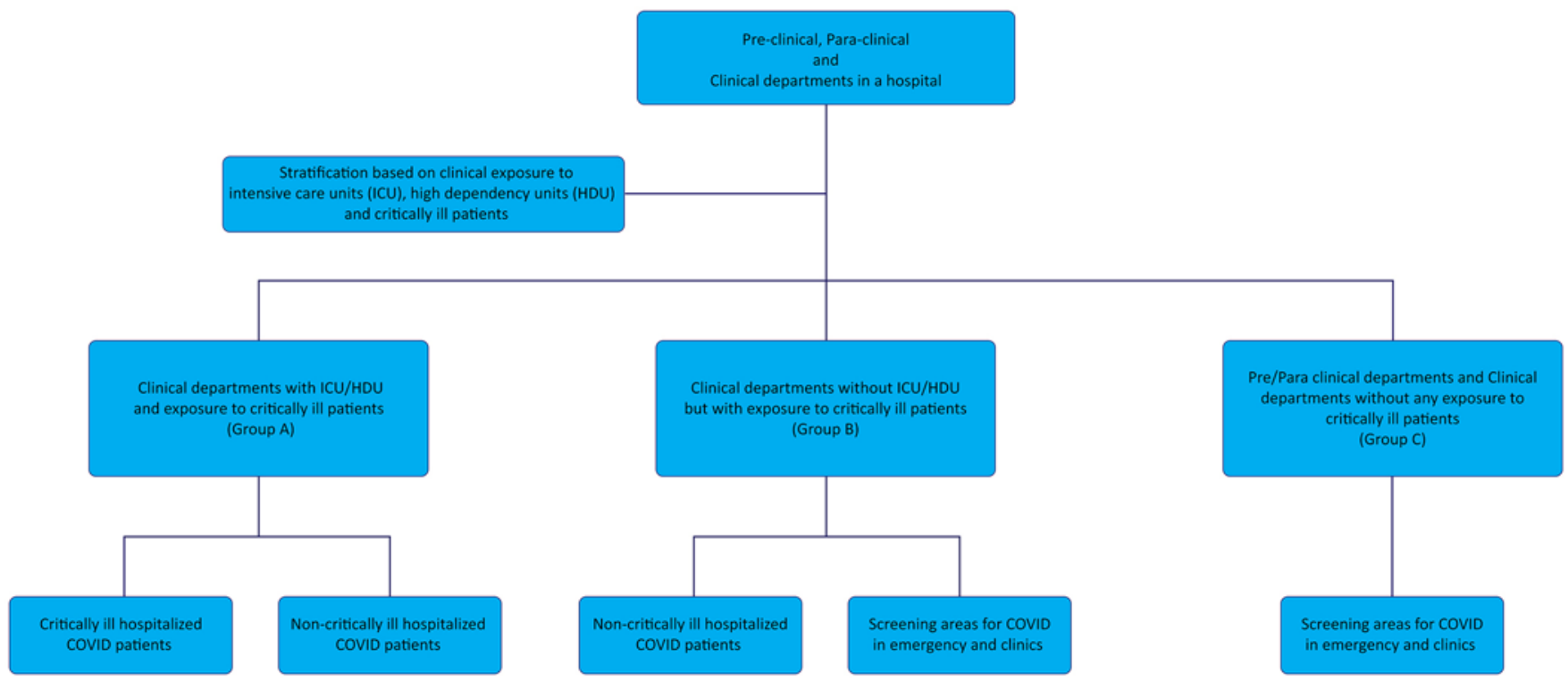

FIG. 4. Template for structured deployment of multidepartment manpower for various facilities designated for the screening and management of COVID-19 patients. Group A departments-anesthesia, critical care, medicine, cardiology, gastroenterology, nephrology, pediatrics, hematology, neurosurgery, neurology, cardiothoracic and vascular surgery, gastrointestinal surgery, pediatric surgery, burns and plastic surgery, and medical oncology. Group B departments-rheumatology, obstetrics and gynecology, endocrinology, orthopedics, radiation oncology, and urology. Group C departments-dermatology, ophthalmology, psychiatry, anatomy, physiology, biochemistry, biophysics, pathology, microbiology, forensic medicine, pharmacology, radiology, and nuclear medicine.

\section{Future Trends and Conclusions}

In the face of adversity and challenge, global collaborative efforts are underway to tackle the COVID-19 pandemic. Relentless efforts to find better diagnostic tools, optimal treatment options, and preventive vaccines have marked a new era in the history of humanity. The advent of artificial intelligence-based diagnostic tools for COVID-19 could help us diagnose early and facilitate contact tracing to contain this virus. ${ }^{48-50}$ The potential impact of the antiviral drug remdesivir in treating severe COVID-19 infections has been validated in recent trials..$^{51-54}$ At the time of this writing, the role of hydroxychloroquine for prophylaxis and as a therapeutic option was still debatable..$^{55-59}$ Innovative techniques, use of technology, consensus building, and adaptability to new evidence-based guidelines are vital for present-day neurosurgeons to optimize patient care and resident training without jeopardizing one's own safety.

\section{Acknowledgments}

We thank the All India Institute of Medical Sciences (AIIMS) COVID-19 Task Force, Human Resource Committee, and Hospital Infection Control Committee, and Neurosurgery Skills Training Facility staff (Mr. Shashi Shekhar and Mr. Trivendra Yadav) for helping with the source material and editing of figures, respectively, for this article. We also thank Dr. G. D. Agrawal (proprietor of Surgiwear) for his contribution in materializing the innovative concept depicted in Fig. 3.

\section{References}

1. American Academy of Otolaryngology-Head and Neck Sur- gery. Academy supports CMS, offers specific nasal policy. Updated March 26, 2020. Accessed October 12, 2020. https: //www.entnet.org/content/academy-supports-cms-offersspecific-nasal-policy

2. American College of Surgeons. COVID-19: recommendations for management of elective surgical procedures. Published March 13, 2020. Accessed October 12, 2020. https:// www.facs.org/covid-19/clinical-guidance/elective-surgery

3. European Association of Neurosurgical Societies. Accessed October 12, 2020. https://www.eans.org/

4. Bajunaid K, Sabbagh AJ, Ajlan A, et al. Consensus statement of the Saudi Association of Neurological Surgery (SANS) on triage of neurosurgery patients during COVID-19 pandemic in Saudi Arabia. Neurosciences (Riyadh). 2020;25(2):148151.

5. Castelnuovo P, Turri-Zanoni M, Karligkiotis A, et al. Skullbase surgery during the COVID-19 pandemic: the Italian Skull Base Society recommendations. Int Forum Allergy Rhinol. 2020;10(8):963-967.

6. Ramakrishna R, Zadeh G, Sheehan JP, Aghi MK. Inpatient and outpatient case prioritization for patients with neurooncologic disease amid the COVID-19 pandemic: general guidance for neuro-oncology practitioners from the AANS/ CNS Tumor Section and Society for Neuro-Oncology. J Neurooncol. 2020;147(3):525-529.

7. Society of British Neurological Surgeons. COVID-19 guidelines. Published 2020. Accessed October 12, 2020. https:// www.sbns.org.uk/index.php/policies-and-publications/covid/

8. Cenzato M, DiMeco F, Fontanella M, et al. Editorial. Neurosurgery in the storm of COVID-19: suggestions from the Lombardy region, Italy (ex malo bonum). J Neurosurg. 2020; 133(1):33-34.

9. Perin A, Servadei F, DiMeco F. May we deliver neuro-oncology in difficult times (e.g. COVID-19)? J Neurooncol. 2020; 148(1):203-205. 
10. Burke JF, Chan AK, Mummaneni V, et al. Letter: The coronavirus disease 2019 global pandemic: a neurosurgical treatment algorithm. Neurosurgery. 2020;87(1):E50-E56.

11. Eichberg DG, Shah AH, Luther EM, et al. Letter: Academic neurosurgery department response to COVID-19 pandemic: the University of Miami/Jackson Memorial Hospital model. Neurosurgery. 2020;87(1):E63-E65.

12. Laskay NMB, Estevez-Ordonez D, Omar NB, et al. Letter: Emergency response plan during the COVID-19 pandemic: the University of Alabama at Birmingham experience. $\mathrm{Neu}$ rosurgery. 2020;87(2):E218-E219.

13. Werner C, Scullen T, Mathkour M, et al. Neurological impact of coronavirus disease of 2019: practical considerations for the neuroscience community. World Neurosurg. 2020;139: 344-354.

14. Planchard R, Lubelski D, Ehresman J, Sciubba D. Telemedicine and remote medical education within neurosurgery. $J$ Neurosurg Spine. 2020;33(4):549-552.

15. Blue R, Yang AI, Zhou C, et al. Telemedicine in the era of coronavirus disease 2019 (COVID-19): a neurosurgical perspective. World Neurosurg. 2020;139:549-557.

16. Germanò A, Raffa G, Angileri FF, et al. Coronavirus disease 2019 (COVID-19) and neurosurgery: literature and neurosurgical societies recommendations update. World Neurosurg. 2020;139:e812-e817.

17. Weiner HL, Adelson PD, Brockmeyer DL, et al. Editorial. Pediatric neurosurgery along with children's hospitals' innovations are rapid and uniform in response to the COVID-19 pandemic. J Neurosurg Pediatr. 2020;26(1):3-5.

18. Ghogawala Z, Kurpad S, Falavigna A, et al. Editorial. COVID-19 and spinal surgery. J Neurosurg Spine. 2020; 33(1):1-3.

19. Kessler RA, Zimering J, Gilligan J, et al. Neurosurgical management of brain and spine tumors in the COVID-19 era: an institutional experience from the epicenter of the pandemic. $J$ Neurooncol. 2020;148(2):211-219.

20. World Health Organization. WHO surveillance case definitions for ILI and SARI. Published January 2014. Accessed October 12, 2020. http://www.who.int/influenza/ surveillance_monitoring/ili_sari_surveillance_case_ definition/en/

21. Centers for Disease Control and Prevention. Coronavirus disease 2019 (COVID-19). Using personal protective equipment (PPE). Updated August 19, 2020. Accessed October 12, 2020. https://www.cdc.gov/coronavirus/2019ncov/hcp/using-ppe.html

22. World Health Organization. How to put on and how to remove personal protective equipment-posters. Published January 2015. Accessed October 12, 2020. http://www.who. int/csr/resources/publications/ebola/ppe-steps/en/

23. Tan YT, Wang JW, Zhao K, et al. Preliminary recommendations for surgical practice of neurosurgery department in the central epidemic area of 2019 coronavirus infection. Curr Med Sci. 2020;40(2):281-284.

24. Indian Council of Medical Research. Accessed October 12, 2020. https://www.icmr.gov.in/

25. Boffa DJ, Judson BL, Billingsley KG, et al. Pandemic recovery using a COVID-minimal cancer surgery pathway. Ann Thorac Surg. 2020;110(2):718-724.

26. Daci R, Natarajan SK, Johnson MD. Letter: Safety considerations for neurosurgical procedures during the COVID-19 pandemic. Neurosurgery. 2020;87(2):E239-E240.

27. Zacharia BE, Eichberg DG, Ivan ME, et al. Letter: Surgical management of brain tumor patients in the COVID-19 era. Neurosurgery. 2020;87(2):E197-E200.

28. Turri-Zanoni M, Battaglia P, Karligkiotis A, et al. Managing care for patients with sinonasal and anterior skull base cancers during the COVID-19 pandemic. Head Neck. 2020; 42(7):1503-1506.
29. Molliqaj G, Schaller K. How neurosurgeons are coping with COVID-19 and how it impacts our neurosurgical practice: report from Geneva University Medical Center. World Neurosurg. 2020;139:624-627.

30. Chibbaro S, Ganau M, Todeschi J, et al. How SARS-CoV-2 is forcing us to reconsider and reorganize our daily neurosurgical practice. Neurochirurgie. 2020;66(4):189-191.

31. Kolias A, Tysome J, Donnelly N, et al. A safe approach to surgery for pituitary and skull base lesions during the COVID-19 pandemic. Acta Neurochir (Wien). 2020;162(7): 1509-1511.

32. COVIDSurg Collaborative. Global guidance for surgical care during the COVID-19 pandemic. Br J Surg. 2020;107(9): 1097-1103.

33. Oudrhiri MY, Bechri H, Hakkou EM, et al. Letter: Neurosurgical patients' management during the COVID-19 pandemic - an institutional report from an African neurosurgical center. Neurosurgery. 2020;87(2):E230-E231.

34. Lo YT, Yang Teo NW, Ang BT. Editorial. Endonasal neurosurgery during the COVID-19 pandemic: the Singapore perspective. J Neurosurg. 2020;133(1):26-28.

35. American Society of Anesthesiologists. The ASA and APSF joint statement on perioperative testing for the COVID-19 virus. Published April 29, 2020. Accessed October 12, 2020. https://www.asahq.org/about-asa/newsroom/ news-releases/2020/04/asa-and-apsf-joint-statement-onperioperative-testing-for-the-covid-19-virus

36. Muhammad S, Tanikawa R, Lawton MT, et al. Letter: Safety instructions for neurosurgeons during COVID-19 pandemic based on recent knowledge and experience. Neurosurgery. 2020;87(2):E220-E221.

37. Coronavirus in the U.S.: latest map and case count. The New York Times. Accessed October 12, 2020. https://www. nytimes.com/interactive/2020/us/coronavirus-us-cases.html

38. Bai Y, Yao L, Wei T, et al. Presumed asymptomatic carrier transmission of COVID-19. JAMA. 2020;323(14):1406-1407.

39. Gandhi M, Yokoe DS, Havlir DV. Asymptomatic transmission, the Achilles' heel of current strategies to control Covid-19. N Engl J Med. 2020;382(22):2158-2160.

40. Lei S, Jiang F, Su W, et al. Clinical characteristics and outcomes of patients undergoing surgeries during the incubation period of COVID-19 infection. EClinicalMedicine. 2020;21: 100331.

41. Mandal S, Bhatnagar T, Arinaminpathy N, et al. Prudent public health intervention strategies to control the coronavirus disease 2019 transmission in India: a mathematical modelbased approach. Indian J Med Res. 2020;151(2-3):190-199.

42. Gangakhedkar GR, Sundaram S, Gangakhedkar MR, Shilotri MP. Hazardous postoperative outcomes of unexpected COVID-19 infected patients: a call for global consideration of sampling all asymptomatic patients before surgical treatment. World J Surg. 2020;44(9):3192-3193.

43. Singhal T. A review of coronavirus disease-2019 (COVID-19). Indian J Pediatr. 2020;87(4):281-286.

44. Grelat M, Pommier B, Portet S, et al. Patients with coronavirus 2019 (COVID-19) and surgery: guidelines and checklist proposal. World Neurosurg. 2020;139:e769-e773.

45. Gupta P, Muthukumar N, Rajshekhar V, et al. Neurosurgery and neurology practices during the novel COVID-19 pandemic: a consensus statement from India. Neurol India. 2020; 68(2):246-254.

46. Zhu W, Huang X, Zhao H, Jiang X. A COVID-19 patient who underwent endonasal endoscopic pituitary adenoma resection: a case report. Neurosurgery. 2020;87(2):E140-E146.

47. Theofanis TN, Khanna O, Stefanelli A, et al. Letter: neurosurgery residency in the COVID-19 era: experiences and insights from Thomas Jefferson University Hospital, Philadelphia, Pennsylvania. Neurosurgery. 2020;87(2):E249.

48. Naudé W. Artificial intelligence vs COVID-19: limitations, 
constraints and pitfalls. AI Soc. Published online April 28, 2020. doi:10.1007/s00146-020-00978-0

49. Shi F, Wang J, Shi J, et al. Review of artificial intelligence techniques in imaging data acquisition, segmentation and diagnosis for COVID-19. IEEE Rev Biomed Eng. Published online April 16, 2020. doi:10.1109/RBME.2020.2987975

50. Vaishya R, Javaid M, Khan IH, Haleem A. Artificial intelligence (AI) applications for COVID-19 pandemic. Diabetes Metab Syndr. 2020;14(4):337-339.

51. Antinori S, Cossu MV, Ridolfo AL, et al. Compassionate remdesivir treatment of severe Covid-19 pneumonia in intensive care unit (ICU) and Non-ICU patients: clinical outcome and differences in post-treatment hospitalisation status. Pharmacol Res. 2020;158:104899.

52. Beigel JH, Tomashek KM, Dodd LE, et al. Remdesivir for the treatment of Covid-19-final report. N Engl J Med. 2020;383: $1813-1826$.

53. Cao YC, Deng QX, Dai SX. Remdesivir for severe acute respiratory syndrome coronavirus 2 causing COVID-19: an evaluation of the evidence. Travel Med Infect Dis. 2020;35: 101647.

54. Singh AK, Singh A, Singh R, Misra A. Remdesivir in COVID-19: a critical review of pharmacology, pre-clinical and clinical studies. Diabetes Metab Syndr. 2020;14(4): 641-648.

55. Cohen MS. Hydroxychloroquine for the prevention of Covid-19-searching for evidence. N Engl J Med. 2020; 383(6):585-586.

56. Das S, Bhowmick S, Tiwari S, Sen S. An updated systematic review of the therapeutic role of hydroxychloroquine in coronavirus disease-19 (COVID-19). Clin Drug Investig. 2020; 40(7):591-601.

57. Ferner RE, Aronson JK. Hydroxychloroquine for COVID-19. What do the clinical trials tell us? Centre for Evidence-Based Medicine; 2020. Accessed October 12, 2020. https://www. cebm.net/covid-19/hydroxychloroquine-for-covid-19-whatdo-the-clinical-trials-tell-us/
58. Rathi S, Ish P, Kalantri A, Kalantri S. Hydroxychloroquine prophylaxis for COVID-19 contacts in India. Lancet Infect Dis. 2020;20(10):1118-1119.

59. Chatterjee P, Anand T, Singh KJ, et al. Healthcare workers \& SARS-CoV-2 infection in India: a case-control investigation in the time of COVID-19. Indian J Med Res. 2020;151(5): 459-467.

\section{Disclosures}

The authors report no conflict of interest concerning the materials or methods used in this study or the findings specified in this paper.

\section{Author Contributions}

Conception and design: Raheja, Agarwal. Acquisition of data: Raheja, Agarwal, Mohapatra, Tandon. Analysis and interpretation of data: Raheja, Agarwal, Mohapatra. Drafting the article: Raheja, Agarwal, Mohapatra. Critically revising the article: Suri, Tandon, Borkar. Reviewed submitted version of manuscript: Suri, Borkar, Chandra, Kale. Approved the final version of the manuscript on behalf of all authors: Suri. Administrative/technical/material support: Chandra, Kale. Study supervision: Suri.

\section{Correspondence}

Ashish Suri: All India Institute of Medical Sciences, New Delhi, India.surineuro@gmail.com. 